\title{
The Impact of Sulphate Corrosion Limitation in Power Boilers on the Properties of Ash from Biomass Combustion
}

\author{
Waldemar Kępys* \\ AGH University of Science and Technology, Faculty of Mining and Geoengineering, Kraków, Poland
}

Received: 17 October 2017

Accepted: 15 February 2018

\begin{abstract}
Due to the content of alkaline compounds, biomass combustion inflicts unfavourable effects on boilers, such as: corrosion, slagging, and fouling of the bed. One of the methods to limit these processes is adding sulphur to the boiler. This article presents the results of studies on the impact of adding sulphur into the boiler (where biomass is combusted), and on the properties of the formed fly ash and bottom ash. As a result, sulphur compounds were mainly in fly ash, which makes it impossible to utilize it in the manner that coal fly ash is normally used.
\end{abstract}

Keywords: biomass combustion, sulphate corrosion, fly ash, bottom ash

\section{Introduction}

The necessity of limiting $\mathrm{CO}_{2}$ emissions coming from the production of electric power and heat makes us produce more and more energy from renewable resources. Fossil fuels such as hard coal and lignite can be partially (co-firing) or wholly replaced by biomass or various waste fuels. The kind of combusted biomass mainly depends on the occurrence of wood industry and agricultural industry, special energy plantations and transport costs. Usually the applied biomass includes: wood, bark, wood chips, corn straw, rape straw, olive pulp, olive kernel, herbaceous biomass, sewage sludge, and animal wastes [1-4]. The co-fired wastes include (among others): coal tailings, petroleum coke, RDF, or tire-derived fuel [1, 5-7].

*e-mail: kepys@agh.edu.pl
The application of biomass instead of coal changed physical and chemical properties of the by-products formed during combustion. This is the result of the change in chemical composition of the fuel itself, as well as adjusting the technology for its combustion. The main mineral components of the ashes coming from the combustion of coal are: silicon-aluminium glaze, quartz, alumina, iron oxide, mullite, and calcium. Apart from this, they contain many trace elements such as: $\mathrm{Ba}$, $\mathrm{Cl}, \mathrm{Cr}, \mathrm{Cu}, \mathrm{F}, \mathrm{Mn}, \mathrm{P}, \mathrm{Pb}, \mathrm{Ti}, \mathrm{Zn}, \mathrm{Zr}$, and $\mathrm{V}$. Comparing the properties of ash from the combustion of coal and biomass in energy combustion, one should state that in the qualitative term the basic composition of elements is the same. Differences occur in the percentage of individual chemical elements [8-11].

The formed by-products of coal combustion in the form of fly ash and bottom ash as well as their mixtures with the residues from the processes of fluegas desulfurization for years have been widely applied in fields such as (among others) in the building industry, 
mining, engineering, and agriculture [9, 12]. This is a result of their physical and chemical properties, fulfilling technical requirements defined in branch standards, as well as environmental requirements mainly related to the protection of water and ground. Biomass ash, like ash coming from coal, can be applied as raw material for the production of cement, concrete, ceramic materials, fertilizers, or soil amendments, or stowing materials used in mining, which are the subject of numerous studies [2, 13-19].

Compared to coal, biomass is characterised by higher content of alkaline compounds $(\mathrm{K}, \mathrm{Ca})$, phosphorus, and chlorine [20]. This results in the occurrence of increased high-temperature corrosion of the heating surface of boilers. Other unfavourable phenomena are slagging and fouling of ash residues in the boiler as a result of the reduction in ash melting points, which can also intensify corrosion [3, 20-23]. The result is reducing the lifespan of the equipment, damage to burner components, and a decrease in combustion efficiency. To prevent these unfavourable phenomena, protective coatings are applied, as well as additives limiting the corrosive impact of chlorine and the phenomena of slagging and fouling of the fluidized bed. The most frequently applied additives are sulphur or its compounds (sulphates of ammonium, aluminium, and iron) and aluminosilicates (kaolin). Additives containing $\mathrm{Ca}$ and $\mathrm{P}$ are also studied [24]. Adding sulphur or its compounds to the hearth causes the emission of $\mathrm{SO}_{3}$ and then sulphation of $\mathrm{KCl}$. For instance, adding ammonium sulphate in the amount of $5 \mathrm{l} / \mathrm{h}$ diminished the amount of gaseous $\mathrm{KCl}$ from 40 to $15 \mathrm{ppm}$ [25]. As a result, $\mathrm{K}_{2} \mathrm{SO}_{4}$ is formed. This is a compound of higher melting point than $\mathrm{KCl}$, which makes it less corrosive [24-26]. On the other hand, the application of the sulphur-containing additives means that its content in ash is higher than could be indicated by its content in biomass. Thus a significant change in chemical properties of the formed ash can occur, which can impact the possibilities of their use. Thus the application of biomass in the energy industry requires research not only on its fuel parameters (heating value, humidity) and the composition of elements in biomass (especially the content of sulphur, chlorine, and alkaline metals) but also the impact of the kind and amount of applied anti-corrosion additives on the properties of solid residues (fly ash and bottom ash).

The article presents the results of the properties of fly ash and bottom ash from the biomass combustion in the bed of the fluidized boiler, to which sulphur is introduced as an anti-corrosive additive. The obtained results are used for assessing changes in the properties of the ash. Moreover, the information contained in the article can be significant in defining the method of limiting the corrosion phenomenon in hearths, and - in case of the application of additives - can also be used in defining the impact of their amount and kind on the formation of ash of the properties allowing their use, which will limit their landfilling.

\section{Materials and Methods}

The studied fly ash (marked as FAB) and bottom ash (marked as BAB) comes from the biomass combustion in circulated fluidized bed boilers. Biomass consisted of wood chips and pellets from sunflower shells, which were mixed together before being added to the boiler. The amount of wood chips was $70-80 \%$ of weight; the rest was the pellets from sunflower shells. Temperature in the bed is $730-760^{\circ} \mathrm{C}$. During biomass combustion, sulphur was added to the fuel in the form of granulate. The amount of added sulphur was regulated by $\mathrm{SO}_{2}$ concentration in exhaust gasses to $22-24 \mathrm{~kg} / \mathrm{h}$. As a comparison, results of the ash from the combustion of coal in the fluidized bed boiler were also analysed. Fly ash from coal combustion was marked as FAC, while bottom ash as BAC.

Grain composition was marked with the use of sieve analysis (for bottom ash) and the laser diffraction method with the application of Analysette 22 made by Fritsch (for fly ash). The samples of ash, prior to chemical composition analysis, were digested using a mixture of $\mathrm{HNO}_{3} / \mathrm{HCl}$ in a microwave oven. The obtained solution was analyzed after dilution by inductively coupled plasma spectrometry/atomic emission spectroscopy (ICP-AES) and by inductively coupled plasma mass spectrometry (ICP-MS) with the use of a Perkin Elmer Elan 6100 apparatus. Leachability tests were conducted according to the EN 12457-2 standard. Distilled water, with a liquid-to-solid ratio (L/S) of 10 , was used as a leaching solution. The suspension was agitated in a plastic flask for 24 hours, then the mixture was filtered through a $0.45 \mu \mathrm{m}$ membrane filter. The resulting leachate was analyzed for $\mathrm{pH}$ and trace elements using ICP-AES and ICP-MS methods. The amount of chlorides was analyzed using the Volhard titration method. Phase composition was examined using a Philips APD PW 3020 X'Pert diffractometer.

\section{Results and Discussion}

Grain composition of ash is presented in Fig. 1. The vast majority of bottom ash grains from biomass combustion (BAB) are smaller than1 $\mathrm{mm}$ (about 94\%), and the size of the biggest grains reached $10 \mathrm{~mm}$. The size of the bottom ash grains BAB is connected with the grain composition of sand added to the bed, the minimum content of which in fraction $0.63-1 \mathrm{~mm}$ was $60 \%$. Compared to the results for bottom ash from coal combustion (BAC), the differences are visible in the content of grains below $700 \mu \mathrm{m}$, the content of which is much higher in bottom ash from coal combustion. The fly ash from biomass combustion (FAB) is characterized by definitely finer granulation (the biggest grains reached the size of $100 \mu \mathrm{m}$ ) than fly ash from coal combustion (FAC), which in about $45 \%$ of cases consisted of grains $<100 \mu \mathrm{m}$, and the size of the biggest grains reached $500 \mu \mathrm{m}$. 


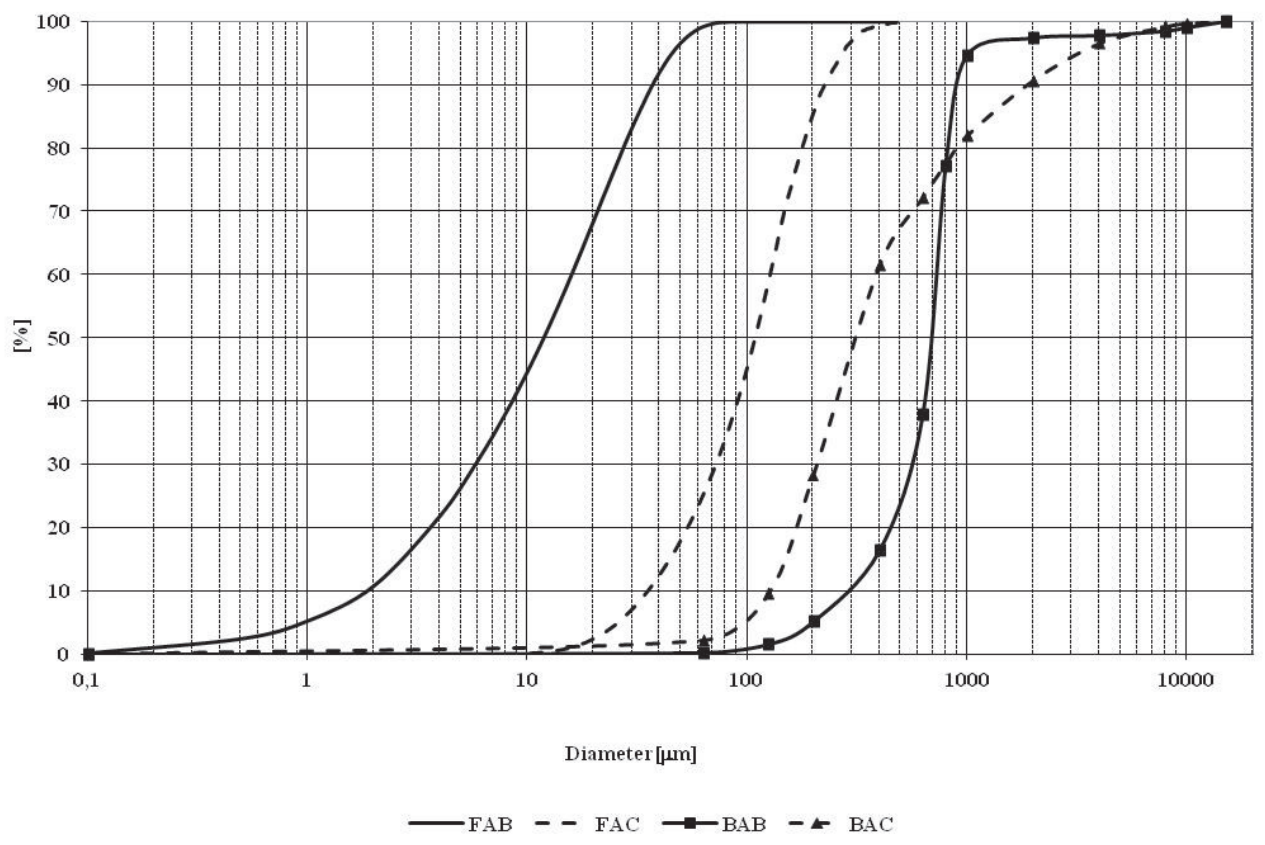

Fig. 1. Grain composition of the studied ash.

The impact of adding sulphur into the boiler, in which biomass was burnt, is visible in the chemical composition of ash, as shown in Table 1 . The content of $\mathrm{SO}_{3}$ in fly ash FAB was above $15 \%$. It is significantly higher content than in fly ash from the combustion of the various types of biomass. According to Vassilev et al. [27], the content of $\mathrm{SO}_{3}$ in ash coming from the combustion of forest biomass originating from the bark of various tree species (beech, birch, spruce) and forest residues ranged from 0.8 to $2.91 \%$ wt., and from sunflower shells it reached

Table 1. Ash chemical composition, trace element content, and leaching test.

\begin{tabular}{|c|c|c|c|c|c|c|c|c|c|c|c|c|}
\hline \multirow{2}{*}{ Symbol of ash } & \multicolumn{12}{|c|}{ Chemical composition (\% wt.) } \\
\hline & $\mathrm{P}_{2} \mathrm{O}_{5}$ & $\mathrm{Mn}_{2} \mathrm{O}_{5}$ & $\mathrm{SiO}_{2}$ & $\mathrm{Al}_{2} \mathrm{O}_{3}$ & $\mathrm{Fe}_{2} \mathrm{O}_{3}$ & \multicolumn{2}{|c|}{$\mathrm{CaO}$} & $\mathrm{M}$ & $\mathrm{gO}$ & $\mathrm{K}_{2} \mathrm{O}$ & $\mathrm{Na}_{2} \mathrm{O}$ & $\mathrm{SO}_{3}$ \\
\hline $\mathrm{BAB}$ & 1.01 & 0.22 & 75.80 & 6.24 & 3.95 & \multicolumn{2}{|c|}{3.58} & 1. & 11 & 1.95 & 0.10 & 0.61 \\
\hline FAB & 7.69 & 0.76 & 21.70 & 8.34 & 2.33 & \multicolumn{2}{|c|}{19.75} & 6. & 47 & 16.71 & 0.19 & 15.20 \\
\hline BAC & 0.11 & 0.02 & 53.30 & 9.01 & 2.84 & \multicolumn{2}{|c|}{24.08} & 0. & 53 & 0.04 & 0.04 & 8.56 \\
\hline \multirow[t]{3}{*}{ FAC } & 0.30 & 0.04 & 59.90 & 4.25 & 1.08 & \multicolumn{2}{|c|}{23.32} & 1. & 09 & 0.57 & 0.44 & 8.14 \\
\hline & \multicolumn{12}{|c|}{ Trace element content (mg/kg) } \\
\hline & As & $\mathrm{Cd}$ & $\mathrm{Cr}$ & $\mathrm{Cu}$ & $\mathrm{Hg}$ & \multicolumn{2}{|c|}{$\mathrm{Ni}$} & \multicolumn{2}{|r|}{$\mathrm{Pb}$} & $\mathrm{Sr}$ & $\mathrm{Ti}$ & $\mathrm{Zn}$ \\
\hline BAB & 9.33 & 1.48 & 21.91 & 344.39 & 0.07 & \multicolumn{2}{|c|}{21.10} & & 175.27 & 95.35 & 186.89 & 3020.52 \\
\hline FAB & 18.64 & 13.37 & 35.03 & 158.50 & 0.18 & \multicolumn{2}{|c|}{23.47} & & 197.75 & 594.12 & 489.12 & 1407.22 \\
\hline BAC & 10.58 & 0.31 & 7.70 & 4.55 & 0.10 & \multicolumn{2}{|c|}{8.92} & & 5.16 & 150.63 & 115.46 & 43.74 \\
\hline \multirow[t]{3}{*}{ FAC } & 13.78 & 0.43 & 12.34 & 29.68 & 0.38 & & .99 & & 25.44 & 237.73 & 270.21 & 74.42 \\
\hline & & & & Concent & tration in & leac & hates ( & $\mathrm{ng} / \mathrm{c}$ & $\left.\mathrm{Im}^{3}\right)$ & & & \\
\hline & $\mathrm{Cd}$ & $\mathrm{Cr}$ & $\mathrm{Cu}$ & $\mathrm{Hg}$ & $\mathrm{Ni}$ & & $\mathrm{Pb}$ & & $\mathrm{Zn}$ & $\mathrm{SO}_{4}$ & & \\
\hline $\mathrm{BAB}$ & 0.0003 & 0.0190 & 0.0005 & 0.0019 & 0.007 & & 0.000 & & 0.0250 & 509.9 & & \\
\hline FAB & 0.0004 & 0.4790 & 0.0015 & 0.0045 & 0.007 & & 0.054 & & 0.0770 & 8480.0 & & 4.0 \\
\hline $\mathrm{BAC}$ & 0.0003 & 0.0002 & 0.0006 & 0.0018 & 0.002 & & $<0.00$ & & $<0.002$ & 613.1 & & \\
\hline FAC & 0.0003 & 0.0310 & 0.0017 & 0.0018 & 0.002 & & 0.013 & & $<0.002$ & 621.1 & & \\
\hline Polish standards & 0.4 & 0.5 & 0.5 & 0.06 & 0.5 & & 0.5 & & 2.0 & 500 & & 00 \\
\hline
\end{tabular}


$4.07 \%$ wt., whereas the contents of remaining compounds in ash FAB are typical for biomass. The amount of $\mathrm{SO}_{3}$ in the studied ash FAB is also higher than the content in fly ash from the combustion of coal in the fluidal boiler FAC, in which the amount of $\mathrm{SO}_{3}$ was $8.1 \%$. Such a high content of sulphates will significantly limit or even disable the use of fly ash from biomass combustion in industries such as construction of buildings or roads. On the other hand, $16.7 \%$ of $\mathrm{K}_{2} \mathrm{O}$ content in ash $\mathrm{FAB}$, at the content of $0.57 \%$ in ash FAC, indicated high participation of potassium contained in biomass and the need of the limitation of the impact of high-temperature corrosion of the heating surfaces of boilers. By the application of sulphur, $\mathrm{K}_{2} \mathrm{SO}_{4}$ (arcanite) was formed, the numerous presence of which was presented on a diffractometer (Fig. 2.). This mineral was not identified in the fly ash from coal FAC. Moreover, another sulphur-containing mineral phase was identified only in fly ash coming from biomass combustion (FAB): syngenite $\mathrm{K}_{2} \mathrm{Ca}\left(\mathrm{SO}_{4}\right)_{2} \cdot \mathrm{H}_{2} \mathrm{O}$. One should mention that both mineral ingredients can occur in ash from biomass or even biomass itself [28-29], but not in such amounts as found in FAB. Chemical and phase composition of the analysed ash coming from biomass combustion proves that the sulphur compounds were located mainly in fly ash; the content of $\mathrm{SO}_{3}$ in bottom ash $\mathrm{BAB}$ was $0.6 \%$. In $\mathrm{BAB}$ the main ingredient is $\mathrm{SiO}_{2}$, the amount of which was above $75 \%$ (Table 1), which was also confirmed by the analysis of phase composition, as presented in Fig. 2. The presence of quartz in bottom ash $\mathrm{BAB}$ and BAC is typical for this kind of ash formed in fluidal boilers, because of the use of quartz sand as bed, and as an effect of getting sand and soil into the biomass in the process of collecting biomass.
The presented chemical composition of the bottom ash BAB shows that the anti-corrosion measures do not negatively impact the chemical composition of the ash, thus it can be a potential material applied for utilisation in various areas.

One of the significant aspects of the utilisation of wastes is environmental aspects, especially the impact of wastes on ground and water environments as defined by the investigation on leaching of chemical pollutants. The results of these studies are also presented in Table 1.

The effect of introducing sulphur to the hearth and getting its compounds into fly ash is very high leaching of sulphates, achieving $8480 \mathrm{mg} / \mathrm{dm}^{3}$. This amount significantly exceeds the maximum allowed content of sulphates in wastewaters that are allowed to get to ground and water environments (e.g., in Poland the maximum amount of sulphates in wastewaters is $500 \mathrm{mg} / \mathrm{dm}^{3}$, the remaining Polish standards of contaminants in wastewater, according of Dz.U. 2014 poz. 1800, are presented in Table 1). Thus the use of the fly ash coming from biomass combustion alone, or even as the component of blends with other materials, e.g., in agriculture, mining, construction, or land reclamation will not be possible or will be significantly limited due to the harmfulness to the ground and water environments, and its management would mean deposition on a landfill. In the case of bottom ash BAB the leaching of sulphates is much lower, thus using it as an ingredient of various materials, e.g., binder and aggregate blends used in the construction industry or land reclamation, should not cause any problem. The analysis of the leachates of other ingredients coming from the analysed ashes showed that, despite the fact that in the chemical composition the amount of heavy

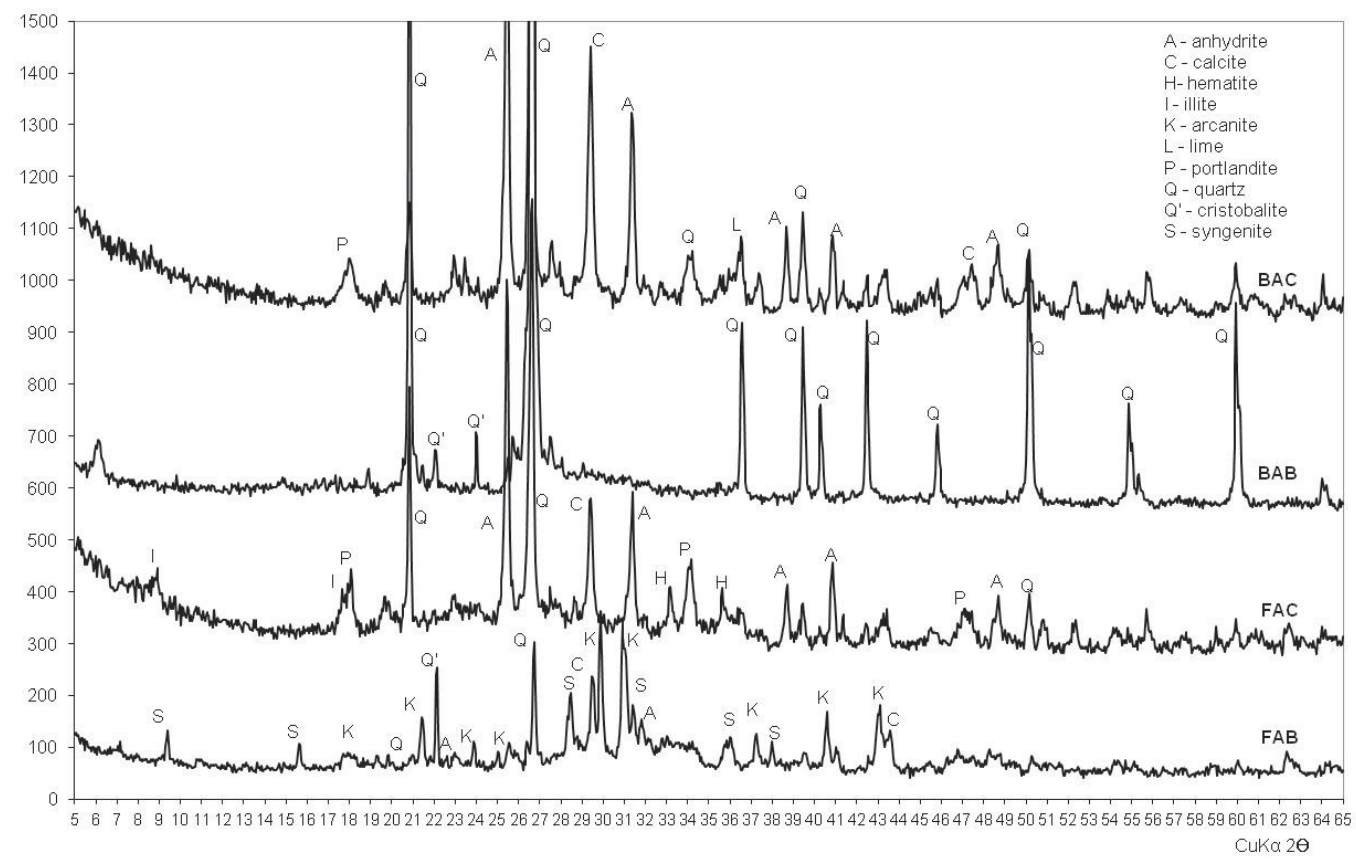

Fig. 2. X-ray diffraction of fly ash and bottom ash. 
metals in ash from biomass was higher than in ash from coal, the solubility of their compounds is very small and should not have a negative impact on the environment.

\section{Conclusions}

Biomass combustion, apart from the benefits such as getting green energy, is also connected with the possibility of the occurrence of technical problems in the work of the boiler. One of the reasons is chemical composition of the combusted biomass, especially the content of alkaline compound causing corrosion of the heating surface of boilers as well as slagging and fouling of the ash in the boiler. One possibility to limit these unfavourable processes is adding sulphur into the boiler. On the other hand, it significantly affects the properties of the formed fly ash. Studies have indicated that as a result of introducing sulphur into the boiler, its compounds are located mainly in fly ash in the form of arcanite and syngenite. The content of $\mathrm{SO}_{3}$ in fly ash exceeded $15 \%$ wt., at the content of $8.1 \% \mathrm{wt}$. in fly ash from the combustion of coal in fluidal boiler, and leaching of sulphates was almost $8500 \mathrm{mg} / \mathrm{dm}^{3}$. Thus the possibilities of using such fly ash are limited, and it turns out that further procedures with ash will be its deposition on a landfill. In the case of bottom ash, the application of sulphur to limit corrosion did not have a negative impact on its chemical properties, and consequently does not limit its use.

\section{Acknowledgements}

This study was conducted under statutory research of the Department of Environmental Engineering and Mineral Raw Material Processing (project No. 11.11.100.482), Faculty of Mining and Geoengineering, AGH University of Science and Technology in Kraków, Poland.

\section{Conflict of Interest}

The authors declare no conflict of interest.

\section{References}

1. IZQUIERDO M., MORENO N., FONT O., QUEROL X., ALVAREZ E., ANTENUCCI D., NUGTEREN H., LUNA Y., FERNÁNDEZ-PEREIRA C. Influence of the co-firing on the leaching of trace pollutants from coal fly ash. Fuel, 87, 1958, 2008.

2. RAJAMMA R., BALL R.J., TARELHO L. A.C., ALLEN G.C., LABRINCHA J.A.,. FERREIRA V.M. Characterisation and use of biomass fly ash in cementbased materials. J. Hazard. Mater., 172, 1049, 2009.
3. TORTOSA MASIÁ A.A., BUHRE B.J.P., GUPTA R.P., WALL T.F. Characterising ash of biomass and waste. Fuel Process. Technol., 88, 1071, 2007.

4. TRYBALSKI K., KĘPYS W., KRAWCZYKOWSKI D., KRAWCZYKOWSKA A., SZPONDER D. Physical Properties of Ash from Co-Combustion of Coal and Biomass. Pol. J. Environ. Stud., 23 (4), 1433, 2014.

5. SHENG G., ZHAI J., LI Q., LI F. Utilization of fly ash coming from a CFBC boiler co-firing coal and petroleum coke in Portland cement. Fuel, 86, 2625, 2007.

6. BARBOSA R., LAPA N., BOAVIDA D., LOPES H., GULYURTLU I., MENDES B. Co-combustion of coal and sewage sludge: Chemical and ecotoxicological properties of ashes. J. Hazard. Mater., 170, 902, 2009.

7. HOWER J.C., ROBERTSON J.D. Chemistry and petrology of fly ash derived from the co-combustion of western United States coal and tire-derived fuel. Fuel Process. Technol., 85, 359, 2004.

8. VASSILEV S.V., MENENDEZ R., ALVAREZ D., DIAZ-SOMOANO M, MARTINEZ-TRAZONA M. R. Phase-mineral and chemical composition of coal fly ashes as a basis for their multicomponent utilization. 1. Characterization of feed coals and fly ashes. Fuel, 82, 1793, 2003.

9. AHMARUZZAMAN M. A review on the utilization of fly ash. Prog. Energ. Combust., 36, 327, 2010.

10. WILLIAMS A., JONES J.M., MA L., POURKASHANIAN M. Pollutants from the combustion of solid biomass fuels Prog. Energ. Combust., 38, 113, 2012.

11. TRYBALSKI K., KĘPYS W., KRAWCZYKOWSKA A., KRAWCZYKOWSKI D., SZPONDER D. Co-Combustion of Coal and Biomass - Chemical Properties of Ash. Pol. J. Environ. Stud., 23 (4), 1427, 2014.

12. NILESH K. MAHALE, SACHIN D. PATIL, DHANANJAY B. SARODE, SANJAY B. ATTARDE. Effect of Fly Ash as an Admixture in Agriculture and the Study of Heavy Metal Accumulation in Wheat (Triticum aestivum), Mung Bean (Vigna radiata), and Urad Beans (Vigna mungo). Pol. J. Environ. Stud., 21 (6), 1713, 2012.

13. ESTEVES T.C., RAJAMMA R., SOARES D., SILVA A.S., FERREIRA V.M., LABRINCHA J.A. Use of biomass fly ash for mitigation of alkali-silica reaction of cement mortars. Constr. Build. Mater., 26, 687, 2012.

14. TKACZEWSKA E., MRÓZ R., ŁÓJ G. Coal-biomass fly ashes for cement production of CEM II/A-V 42.5R. Constr. Build. Mater., 28, 633, 2012.

15. WANG S., MILLER A., LLAMAZOS E., FONSECA F., BAXTER L. Biomass fly ash in concrete: Mixture proportioning and mechanical properties. Fuel, 87, 365, 2008.

16. KIZINIEVIC O., KIZINIEVIC V. Utilisation of wood ash from biomass for the production of ceramic products. Constr. Build. Mater., 127, 264, 2016.

17. RUIZ .B, GIRÓN R.P., SUÁREZ-RUIZ I., FUENTE E. From fly ash of forest biomass combustion (FBC) to micro-mesoporous silica adsorbent materials. Process Saf. Environ., 105, 164, 2017.

18. JIMÉNEZ I., PÉREZ G., GUERRERO A., RUIZ B. Mineral phases synthesized by hydrothermal treatment from biomass ashes. Int. J. Miner. Proc., 158, 8, 2017.

19. KĘPYS W., PIOTROWSKI Z., POMYKAŁA R., GRZYWA A. Application of fly ash from biomass in suspension technologies. Inżynieria Mineralna-J. Pol. Min. Eng. Soc., 15, (2), 251, 2014. 
20. NUNES L.J.R., MATIAS J.C.O., CATALÃO J.P.S. Biomass in the generation of electricity in Portugal: A review. Renew. Sustain. Energ. Rev., 71, 373, 2017.

21. PRONOBIS M. The influence of biomass co-combustion on boiler fouling and efficiency. Fuel 85, 474, 2006.

22. DEMIRBAS A. Potential applications of renewable energy sources, biomass combustion problems in boiler power systems and combustion related environmental issues. Prog. Energ. Combust., 31, 171, 2005.

23. YIN CH., ROSENDAHL L.A., KÆR S.K. Grate-firing of biomass for heat and power production. Prog. Energ. Combust., 34, 725, 2008.

24. WANG L., HUSTADA J.E., SKREIBERG Ø., SKJEVRAK G., GRØNLI M. A critical review on additives to reduce ash related operation problems in biomass combustion applications. Energy Proced., 20, 20, 2012.

25. HUPA M., KARLSTRÖM O., VAINIO E. Biomass combustion technology development - It is all about chemical details. P.Combust. Inst., 36, 113, 2017.
26. NIU Y. TAN H., HUI S. Ash-related issues during biomass combustion: Alkali-induced slagging, silicate meltinduced slagging (ash fusion), agglomeration, corrosion, ash utilization, and related countermeasures. Prog.Energ. Combust., 52 1, 2016.

27. VASSILEV S.V., BAXTER D., ANDERSEN L.K., VASSILEVA CH. G. An overview of the chemical composition of biomass. Fuel, 89, 913, 2010.

28. VASSILEV S.V., BAXTER D., VASSILEVA CH.G. An overview of the behaviour of biomass during combustion: Part II. Ash fusion and ash formation mechanisms of biomass types. Fuel, 117, 152, 2014.

29. VASSILEV S.V., BAXTER D., ANDERSEN L.K., VASSILEVA CH.G., MORGAN T.J. An overview of the organic and inorganic phase composition of biomass. Fuel, 94, 1, 2012. 